\title{
THE IMPORTANCE OF SPECIALIZED INTERNSHIP FOR THE PHYSICAL THERAPY AND SPECIAL MOTOR SKILLS IN IMPROVING THEIR PROFESSIONAL SKILLS
}

\author{
Balint Nela Tatiana1* \\ Anghel Mihaela ${ }^{2}$ \\ 1,2"Vasile Alecsandri" University of Bacău,157 Marasesti Av., 600115, Romania
}

Keywords: internship, experience, transition.

\begin{abstract}
Within two SOPHRD projects, the participation of 60 undergraduate students from the "Vasile Alecsandri" University of Bacau, Faculty of Human Movement, Sports, and Health Sciences, constituted an opportunity for facilitating the specialized internship. The goals were to: increase the future graduates' awareness in regards to their opportunities for internship and dissemination of good practices that help them with a better insertion in the labor market; improve the professional orientation of 30 students through innovative actions of professional counseling and career orientation, aiming to develop the necessary skills for the labor market and increase their chances; facilitate the students' access to effective internships, developing public and private partnerships, through mechanisms of the project between universities and employers, aiming to improve the transition from school to a productive life.
\end{abstract}

\section{Introduction}

This paper tries to emphasize the role of successful partnerships between academia and employers, aiming to increase and develop the students' knowledge and working skills, to facilitate their optimal insertion in the labor market, using the project co-funded by the European Social Fund, through the Sectoral Operational Programme for Human Resources Development 20072013. The effect of these integrated measures of stimulating the acquiring of knowledge and developing the working skills in the students through internships at various potential employers, is to facilitate the transition from school to a productive life in an effective manner, acquiring professional skills up to the standards of the labor market, to reduce unemployment, especially among new graduates, to reduce the effects of the current economic crisis, and to satisfy the graduates' need to adapt to the demands of the labor market and of the employers.

*E-mail: balint.tatiana@gmail.com, tel.0744680507 
It has been observed that there is a need for the young students to benefit from internships that are adapted to their needs, in the fields they specialize at a higher education level, in this case, Physical Therapy and Special Motor Skills. This type of projects are even more valuable if one considers the fact that currently there are no bodies that would facilitate internships, the students being forced to look for themselves a place where they could hone their skills.

Below there is a presentation of the two hosting institutions within the two projects developed in partnership with the "Vasile Alecsandri" University of Bacau, through the Faculty of Human Movement, Sports, and Health Sciences:

- The "Episcop Melchisedec" Foundation - the Bacau branch, for the project Increasing the employability of the students through effective internships, professional counseling and career orientation - One extra chance! The foundation offers social-medical, community, educational, cultural, ecological, and volunteer programs for the people in crisis, in need of financial support, of access to quality social services, to education, health, socializing, social reintegration. The internship activities took place at the Neuromotor Rehabilitation Center "Sf. Vasile cel Mare" - Bacău.

- The "Sfântul Voievod Ştefan cel Mare" - Hârja, for the project Supporting the students in the transition towards a productive life through specialized internships, career orientation and professional counseling - Support for the future! The social services offered by this association, through the SocialMedical Center for elderly people "Sf. Voievod Ştefan cel Mare" - Hârja, represent a complex ensemble of measures and actions performed to satisfy the social and medical individual, family or group needs, to prevent and overcome certain difficult, vulnerable moments, to preserve the persons' autonomy and protection, to prevent their marginalization and social exclusion, to promote social inclusion and to increase the quality of life.

\section{Research Hypotheses}

- presumably, through the students' learning and developing professional skills within partnerships between academia and private employers, one can contribute to the development of the skills needed for a successful integration in the labor market and the increase of the employment rate;

- presumably, by facilitating the students' access to effective internships, one can contribute to the improvement of the transition from school to a productive life.

\section{Material and methods}

The study was conducted between August 03, 2015 and October 31, 2015. At the Bacau branch of the "Episcop Melchisedec" Foundation, through the Neuromotor Rehabilitation Center "Sf. Vasile cel Mare" of Bacău, a number of 30 students participated in the study. Out of these, 7 students were second year undergraduates, 23 first year undergraduates, 9 males and 21 females, aged between 19 and 36, with 14 from a rural environment and 16 from an urban environment. At the "Sfântul Voievod Ştefan cel Mare" Association, through the 
Social-Medical Center for elderly people "Sf. Voievod Ştefan cel Mare" - Hârja, a number of 30 students participated in the study. Out of these, 25 students were second year undergraduates, 3 third year undergraduates and 2 first year graduate students, 10 males and 20 females, aged between 19 and 23, with 7 from a rural environment and 23 from an urban environment.

The students were divided into four groups, each student going through 14 days of internship of 6 hours a day, totaling 84 hours of internship. During this period, the students benefited from a physical therapy tutor from the centers organizing the internships and from a supervising teacher from the Department of Physical Therapy and Occupational Therapy.

The internship took place during the summer vacation, and was in accordance with Order no. 3955 of May 9, 2008, published in the Official Gazette, Part I no. 440 of June 12, 2008 regarding the general framework for the organization of internships within undergraduate and graduate university study programs.

\section{Results and discussions}

After applying to the 60 students the final questionnaires containing 10 questions, at the end of the internships, the results for 5 of the questions were selected and interpreted as follows:

1. How do you assess your collaboration with the specialists at the internship center?

\begin{tabular}{|c|c|c|c|}
\hline Very good & Good & Satisfactory & Unsatisfactory \\
\hline 53 & 6 & & 1 \\
\hline
\end{tabular}

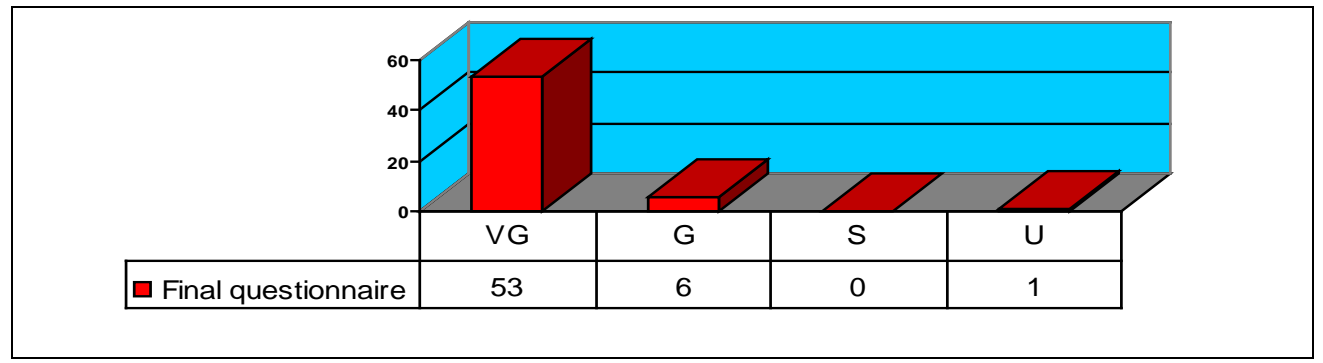

Figure 1. Dynamics of the results' progress regarding question 1

As seen in Figure 1, regarding the dynamics of the results' progress for question 1 , one can observe an unidirectional distribution of the results towards a very good assessment (80.8\%), a good assessment (10\%), and unsatisfactory (1.6\%).

2. How do you assess the allocation of time for the various practical activities? 
Balint Nela Tatiana, Anghel Mihaela/ Gymnasium

\begin{tabular}{|c|c|c|c|c|}
\hline \hline Very good & Good & \multicolumn{2}{c|}{ Satisfactory } & Unsatisfactory \\
\hline 34 & 24 & \multicolumn{2}{c|}{2} \\
\hline & & \\
\hline
\end{tabular}

Figure 2. Dynamics of the results' progress regarding question 2

As seen in Figure 2, regarding the dynamics of the results' progress for question 2, one can observe a bimodal distribution of the results towards a very good assessment (56\%), a good assessment (40\%), and satisfactory (3.3\%).

3. How important, adequate, opportune, and explicit did the practical examples seem to you?

\begin{tabular}{|c|c|c|c|}
\hline Very good & Good & Satisfactory & Unsatisfactory \\
\hline 52 & 7 & 1 & \\
\hline
\end{tabular}

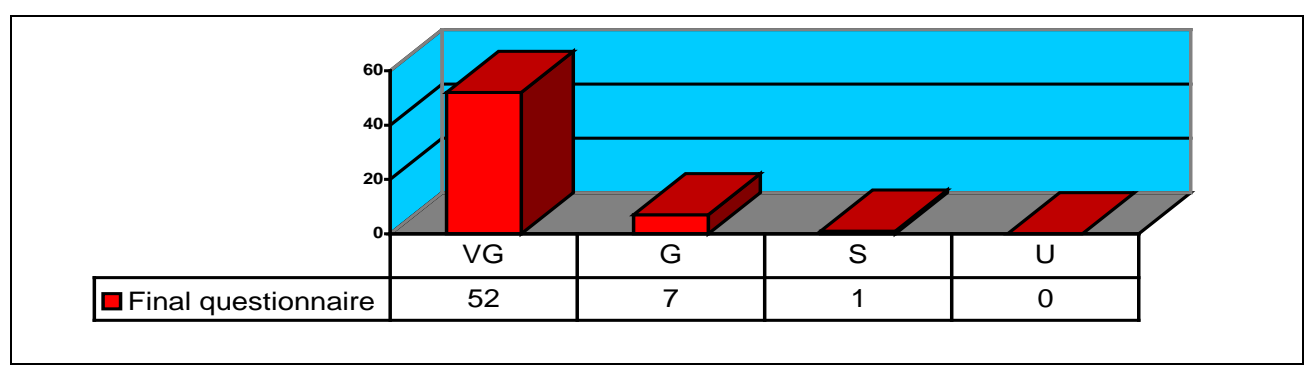

Figure 3. Dynamics of the results' progress regarding question 3

As seen in Figure 3, regarding the dynamics of the results' progress for question 3, one can observe an unidirectional distribution of the results towards a very good assessment (80.6\%), a good assessment (11.6\%), and satisfactory (1.6\%).

4. How do you assess the student-tutor relationship? Please write: VG (very good), G (good), S (satisfactory) or U (unsatisfactory).

\begin{tabular}{|c|c|c|c|c|}
\hline Work style & $\begin{array}{c}\text { Way of } \\
\text { presenting the } \\
\text { examples }\end{array}$ & $\begin{array}{c}\text { Communication } \\
\text { and feedback } \\
\text { skills }\end{array}$ & $\begin{array}{c}\text { Knowing the } \\
\text { subject }\end{array}$ & $\begin{array}{c}\text { General } \\
\text { assessment }\end{array}$ \\
\hline $\begin{array}{c}\mathrm{VG}-53 / \mathrm{G}- \\
6 / \mathrm{U}-1\end{array}$ & $\begin{array}{c}\mathrm{VG}-52 / \mathrm{G}- \\
\mathrm{VG}-45 / \mathrm{S}-1\end{array}$ & $13 / \mathrm{S}-2$ & $\mathrm{VG}-44 / \mathrm{G}-$ & $\mathrm{VG}-49 / \mathrm{G}-$ \\
& & $14 / \mathrm{S}-2$ & $9 / \mathrm{S}-2$ \\
\hline
\end{tabular}




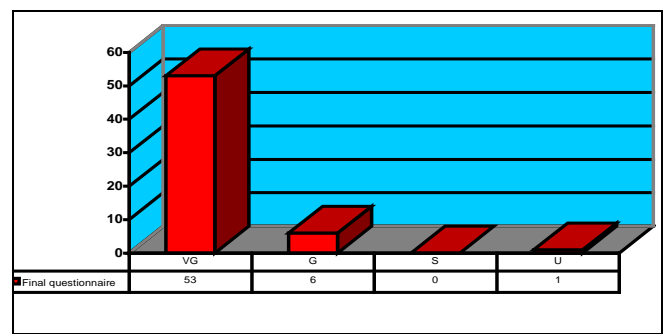

Figure 4. Dynamics of the results' progress regarding question 4 - Work style

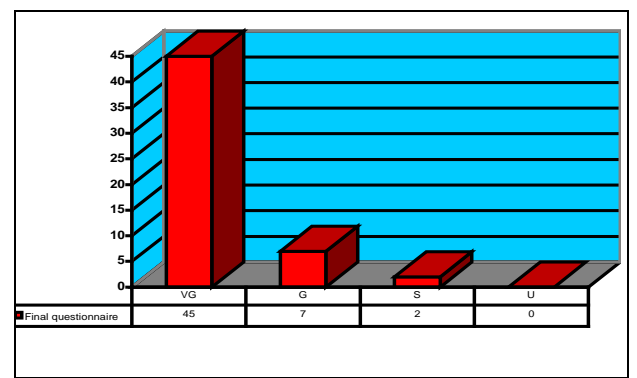

Figure 6. Dynamics of the results' progress regarding question 4 Communication and feedback skills

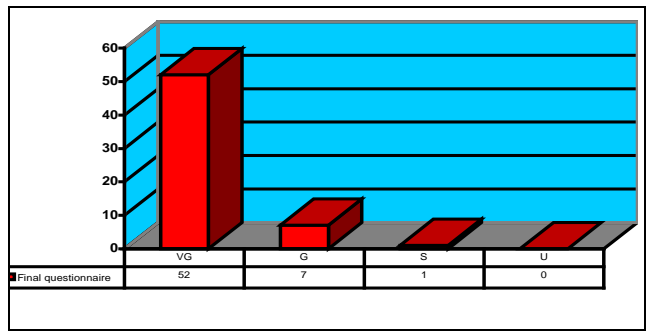

Figure 5. Dynamics of the results' progress regarding question 4 - Way of presenting the examples

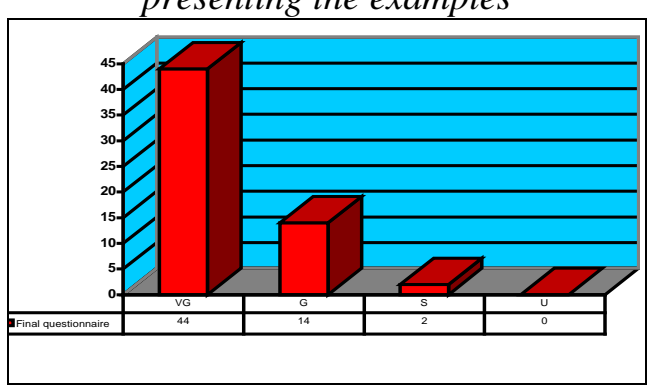

Figure 7. Dynamics of the results' progress regarding question 4 - Knowing the subject

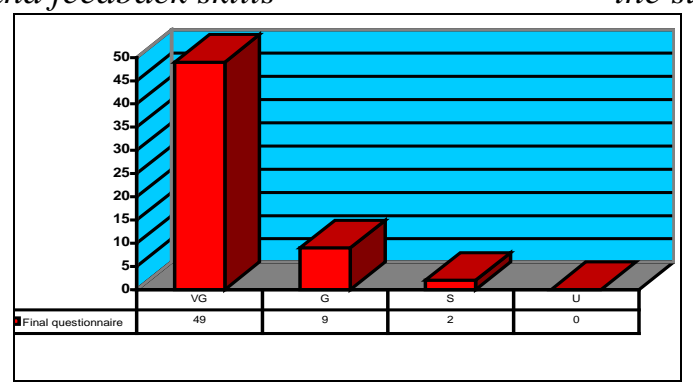

Figure 8. Dynamics of the results' progress regarding question 4 - General assessment

As seen in Figure 4, regarding the dynamics of the results' progress for question 4 - Work style, one can observe an unidirectional distribution of the results towards a very good assessment (80.8\%), a good assessment (10\%), and unsatisfactory (3.3\%). As seen in Figure 5, regarding the dynamics of the results' progress for question 4 - Way of presenting the examples, one can observe an unidirectional distribution of the results towards a very good assessment (80.6\%), a good assessment (11.6\%), and unsatisfactory (1\%). As seen in Figure 6, regarding the dynamics of the results' progress for question 4 Communication and feedback skills, one can observe an unidirectional distribution of the results towards a very good assessment (75\%), a good assessment (21.6\%), and unsatisfactory (3.3\%). As seen in Figure 7, regarding the dynamics of the results' progress for question 4 - Knowing the subject, one can observe an unidirectional distribution of the results towards a very good assessment (73\%), a good assessment (23.3\%), and unsatisfactory (3.3\%). As 
seen in Figure 8, regarding the dynamics of the results' progress for question 4 General assessment, one can observe an unidirectional distribution of the results towards a very good assessment (81.6\%), a good assessment (15\%), and unsatisfactory (3.3\%).

5. Do you think that the internship has contributed to your professional training and to your adaptation to your future practical activity, thus facilitating your access to the labor market?

\begin{tabular}{|c|c|c|c|}
\hline Very much & Much & Significantly & Not at all \\
\hline 47 & 12 & 1 & \\
\hline
\end{tabular}

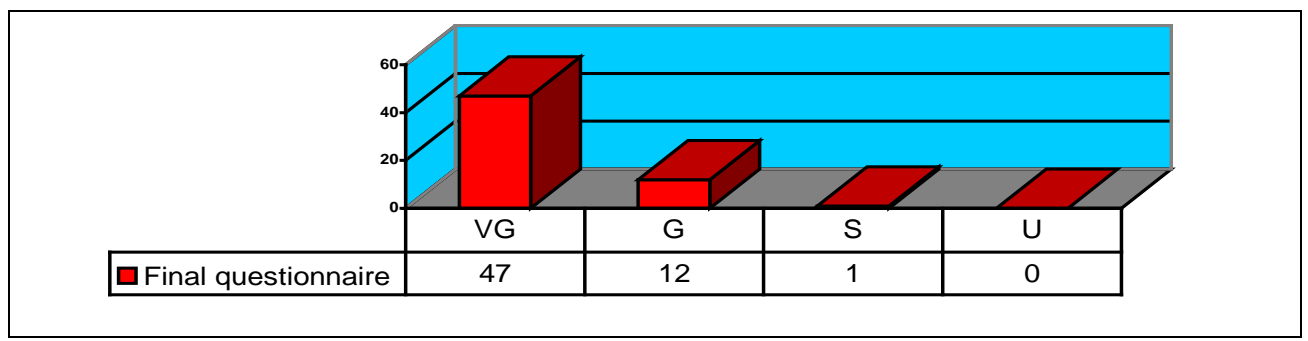

Figure 9. Dynamics of the results' progress regarding question 5

As seen in Figure 9, regarding the dynamics of the results' progress for question 5, one can observe an unidirectional distribution of the results towards a very good assessment (78.3\%), a good assessment (20\%), and unsatisfactory (1\%).

\section{Conclusions}

The general conclusions that were drawn at the end of the project were as follows:

Out of the professional and transversal skills (according to the Matrix of the National Framework for Higher Education Qualifications NFHEQ Grid 1L Description of the field/study program through professional skills and transversal skills, http://portal.unitbv.ro/) offered by the internship activities performed in the aforementioned centers, the following are to be retained:

\begin{tabular}{|c|c|}
\hline General and specific transversal skills & Professional skills \\
\hline $\begin{array}{l}\text { - The responsible performance of } \\
\text { professional tasks, under conditions of } \\
\text { restrained autonomy and qualified } \\
\text { assistance - The organization of physical } \\
\text { therapy programs with qualified assistance, } \\
\text { respecting the professional ethical and } \\
\text { deontological standards; } \\
\text { - The familiarization with the specific } \\
\text { team work roles and activities, and task } \\
\text { distribution for subordinates - Completing }\end{array}$ & $\begin{array}{l}\text { - The primary (functional) } \\
\text { clinical assessment, and } \\
\text { diagnosing the physical therapy } \\
\text { intervention needs; } \\
\text { - The creation of the physical } \\
\text { therapy prophylactic, curative, or } \\
\text { rehabilitative programs; } \\
\text { - The use of physical therapy } \\
\text { intervention methods and } \\
\text { techniques; }\end{array}$ \\
\hline
\end{tabular}




\begin{tabular}{|l|l|}
\hline $\begin{array}{l}\text { efficiently and effectively work tasks for the } \\
\text { organization and development of specific } \\
\text { physical therapy intervention activities; }\end{array}$ & $\begin{array}{l}\text { The use of management and } \\
\text { marketing elements that are } \\
\text { specific to this field. }\end{array}$ \\
- Being aware of the need for a continuous & \\
education; using effectively the learning & \\
resources and techniques for a successful & \\
personal and professional development - & \\
The objective self-assessment of one's need & \\
for a continuous professional education for & \\
a good insertion into and adaptation to the & \\
labor market, according to one's own \\
personal development project.
\end{tabular}

The general conclusions that were drawn at the end of the project were as follows:

- the knowledge, skills and competences acquired by the participants after finishing their internships will help them adapt much easier to the new demands of the work market;

- as a result of the development and improvement of professional skills, they can have a positive impact on the economic and social life, as a whole.

This paper was based on the activities performed for the SOPHRD projects, 189/2.1/G/156348 - "Increasing the employability of the students through effective internships, professional counseling and career orientation One extra chance!" and 189/2.1/G/156336 - "Supporting the students in the transition towards a productive life through specialized internships, career orientation and professional counseling - Support for the future!."

\section{References}

1. ${ }^{* * *}$ The Matrix of the National Framework for Higher Education Qualifications NFHEQ Grid 1L - Description of the field/study program through professional skills and transversal skills, http://portal.unitbv.ro/Retrieved February 2016;

2. *** Order no. 3955 of May 9, 2008, published in the Official Gazette, Part I no. 440 of June 12, 2008;

3. ${ }^{* * *}$ SOPHRD 189/2.1/G/156348, Increasing the employability of the students through effective internships, professional counseling and career orientation - One extra chance!;

4. ${ }^{* * *}$ Guide of good practices, Increasing the employability of the students through effective internships, professional counseling and career orientation - One extra chance! http://www.epr.ro/proiectul-o-sansa-plus-la-final, Retrieved 17.02.2015;

5. ${ }^{* * *}$ SOPHRD 189/2.1/G/156336, Supporting the students in the transition towards a productive life through specialized internships, career orientation and professional counseling - Support for the future!; 
6. ${ }^{* * *}$ Guide of good practices, (2015). Supporting the students in the transition towards a productive life through specialized internships, career orientation and professional counseling - Support for the future!

\title{
IMPORTANTTA STAGIILOR DE PRACTICĂ DE SPECIALITATE PENTRU STUDENT II DE LA SPECIALIZAREA KINETOTERAPIE ŞI MOTRICITATE SPECIALĂ ÎN ÎMBUNĂTĂŢIREA COMPETENŢELOR PROFESIONALE
}

\author{
Balint Nela Tatiana ${ }^{1}$ \\ Anghel Mihalea ${ }^{2}$ \\ 1,2University of Bacău "Vasile Alecsandri",157 Marasesti Av., 600115, România,
}

Keywords: practică, experienţă, tranziţie.

\begin{abstract}
În cadrul a două proiecte de tip POSDRU participarea unui număr de 60 studenți din Universitatea „Vasile Alecsandri” din Bacău de la Facultatea de Ştiinţe ale Mişcării Sportului şi Sănătăţii, a constituit o oportunitate pentru facilitarea stagiilor de practică de specialitate. Obiectivele propuse au fost: creşterea gradului de conştientizare privind oportunităţile viitorilor absolvenţi de învăţământ superior pentru efectuarea stagiilor de practică şi diseminarea de bune practici ce vin în ajutorul unei inserţii optime pe piaţa muncii; Imbunătăţirea orientării profesionale a 30 de studenţi prin acţiuni inovatoare de consiliere profesională şi orientare în carieră cu scopul dezvoltării competenţelor necesare în procesul inserării pe piaţa muncii şi creşterea gradului de ocupare; Facilitarea accesului la stagii de practică performante pentru studenţi în vederea creşterii ratei de ocupare prin dezvoltarea de parteneriate public private, prin mecanisme ale proiectului între universităţi şi angajatori în vederea îmbunătăţirii tranziţiei de la şcoală la o viaţă activă.
\end{abstract}

\section{Introducere}

În cadrul acestei lucrări ne-am propus să evidenţiem, rolul parteneriatelor performante între mediul academic şi angajatori cu scopul dobândirii şi dezvoltării cunoştinţelor şi a aptitudinilor de muncă ale studenţilor pentru facilitarea unei inserţii optime a acestora pe piaţa muncii în cadrul proiectul cofinanţat din Fondul Social European prin Programul Operaţional Sectorial Dezvoltarea Resurselor Umane 2007-2013. Efectul acestor măsuri integrate de stimulare a dobândirii cunoştinţelor şi dezvoltării aptitudinilor de muncă ale tinerilor prin efectuarea de stagii de practică pentru studenţi, la diferiţi potenţiali angajatori, este de a facilita tranziţia de la şcoală la viaţa activă într-un mod performant prin dobândirea de competenţe profesionale la standardul cerut pe piaţa muncii şi de a atenua efectele creşterii şomajului, în special în rândul proaspeţilor absolvenţi, restructurării economice actuale şi ale necesităţii 
adaptării la cerinţele pieţii muncii şi a angajatorilor.

Constatăm o reală nevoie şi o necesitate pentru tinerii studenţi de a beneficia de participarea la stagii de practică adaptate nevoilor lor, în domeniile în care se specializează în cadrul învăţământului superior şi anume în Kinetoterapie şi motricitate specială. Aceste tipuri de proiecte aduc un plus de valoare şi prin faptul că în momentul de faţă nu există entităţi facilitatoare pentru organizarea stagiilor de practică şi pune în responsabilitatea studentului de a-şi căuta un loc de practică.

În continuare, se impune prezentarea celor două instituţii gazdă în cadrul celor două proiecte derulate în parteneriat cu Universitatea „Vasile Alecsandri” din Bacău prin Facultatea de Ştiinţe ale Mişcării Sportului şi Sănătăţii şi anume:

- Fundaţia „Episcop Melchisedec” - Filiala Bacău pentru proiectul Creşterea angajabilităţii personale a studenţilor prin stagii de practică performante, consiliere profesională şi orientare în carieră - $O$ şansă în plus!. Fundaţia oferă programe socio-medicale, comunitare, educative, culturale, ecologice şi de voluntariat oferite persoanelor aflate în situaţii de criză, sprijin material, acces la servicii sociale de calitate, la educaţie, sănătate, socializare, reintegrare socială. Activităţile de practică cu studenţii s-au desfăşurat la Centrul de recuperare neuromotorie „Sfântul Vasile cel Mare” - Bacău.

- Asociaţia „Sfântul Voievod Ştefan cel Mare” - Hârja pentru proiectul Sprijinirea studenţilor în tranziţia spre viaţa activă prin stagii de practică specializate, orientare în carieră şi consiliere profesională - Sprijin pentru viitor!. Serviciile sociale oferite prin această asociaţie şi anume Centrul SocialMedical pentru persoane vârstnice „Sf. Voievod Ştefan cel Mare” - Hârja, reprezintă ansamblul complex de măsuri şi acţiuni realizate pentru a răspunde nevoilor sociale şi medicale individuale, familiale sau de grup, în vederea prevenirii şi depăşirii unor situaţii de dificultate, vulnerabilitate sau dependenţă pentru prezervarea autonomiei şi protecţiei persoanei, pentru prevenirea marginalizării şi excluziunii sociale, pentru promovarea incluziunii sociale şi în scopul creşterii calităţii vieţii.

Ipotezele cercetării

- se presupune, că prin dobândirea şi dezvoltarea cunoştinţelor şi a aptitudinilor de muncă ale studenţilor în cadrul parteneriatelor profesionale între mediu academic şi cel privat putem contribui la dezvoltării competenţelor necesare în procesul inserării pe piaţa muncii şi creşterea gradului de ocupare;

- $\quad$ se presupune, că prin facilitarea accesului la stagii performante pentru studenţi putem contribui la îmbunătăţirea tranziţiei de la şcoală la o viaţă activă.

\section{Material şi metode}

Cercetarea s-a desfãşurat în perioada 3 august 2015 - 31 octombrie 2015. În cadrul Fundatiei "Episcop Melchisedec" Filiala Bacău prin Centrul de recuperare neuromotorie „Sf. Vasile cel Mare” din Bacău au participat un număr de 30 de 
studenţi. Menţionăm că dintre aceştia 7 studenţi au fost din anul II de studiu, 23 din anul I de studiu, 9 de sex masculin şi 21 de sex femeiesc cu vârsta cuprinsă între 19 - 36 ani, mediul de provenienţă a fost reprezentat de 14 persoane din mediul rural şi 16 din mediul urban. Iar în cadrul Asociaţiei „Sfântul Voievod Ştefan cel Mare” Hârja prin Centrul Social-Medical pentru persoane vârstnice „Sf. Voievod Ştefan cel Mare” - Hârja au participat un număr de 30 de studenţi. Menţionăm că dintre aceştia 25 studenţi au fost din anul II de studiu, 3 din anul III de studiu şi 2 studenţi masterat anul I, 10 de sex masculin şi 20 de sex feminin cu vârsta cuprinsă între 19 - 23 ani, mediul de provenienţă a fost reprezentat de 7 persoane din mediul rural şi 23 din mediul urban.

Studenţii au fost împărţiţi în patru grupe, fiecare student efectuând un număr de 14 zile de practică a câte 6 ore pe zi în total 84 de ore de practică. În această perioadă studenţii au beneficiat de câte un tutore de practică kinetoterapeut din partea centrelor furnizoare de practică şi de un cadru didactic supervizor din partea Departamentului de Kinetoterapie şi Terapie Ocupaţională.

Efectuarea stagiului de practică în perioada de vacanţă a avut la bază respectarea Ordinului nr. 3955 din 9/05/2008 publicat în Monitorul Oficial, Partea I nr. 440 din 12/06/2008 privind cadrul general de organizare a stagiilor de practică în cadrul programelor de studii universitare de licenţă şi masterat.

\section{Rezultate şi discuţii}

În urma chestionarelor finale aplicate celor 60 de studenţi cu 10 întrebări aplicate la finalizarea stagiilor de practică, selectăm rezultatele obţinute pentru 5 dintre întrebări şi realizăm interpretarea acestora astfel:

1. Cum aţi aprecia colaborarea cu specialiştii din centrul de practică?

\begin{tabular}{|c|c|c|c|}
\hline Foarte bună & Bună & Satisfăcătoare & Nesatisfăcătoare \\
\hline 53 & 6 & & 1 \\
\hline
\end{tabular}

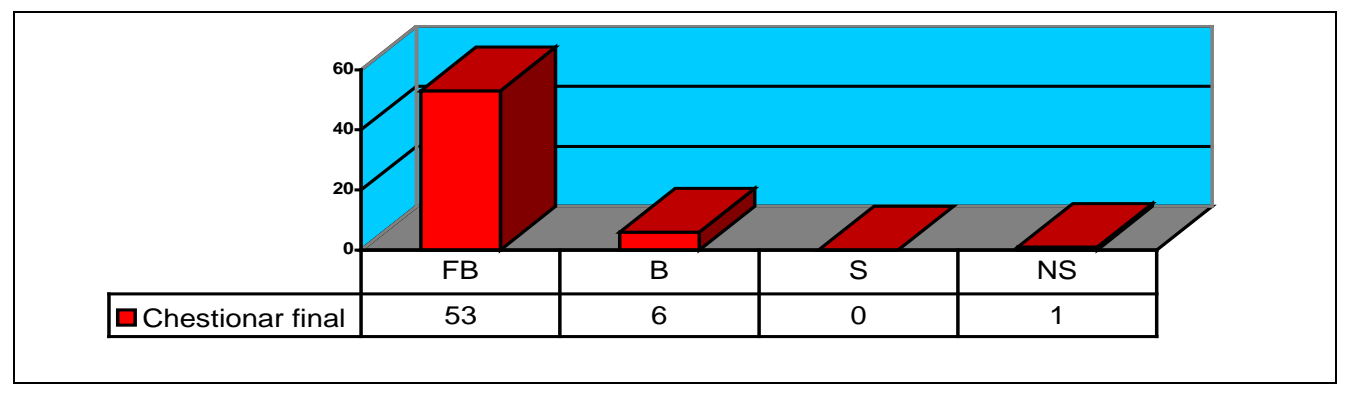

Figura 1. Dinamica evoluţiei rezultatelor pentru întrebarea 1

Conform graficului 1 privind dinamica evoluţiei rezultatelor pentru întrebarea 1, putem constata o distribuţie unidirecţionată a rezultatelor către o apreciere foarte bună $80,8 \%$, o apreciere bună $10 \%$ iar nesatisfăcătoare $1,6 \%$.

2. Cum aţi aprecia alocarea timpului pentru diferitele teme practice abordate? 


\begin{tabular}{|c|c|c|c|}
\hline Foarte bun & Bun & Satisfăcător & Nesatisfăcător \\
\hline 34 & 24 & 2 & \\
\hline
\end{tabular}

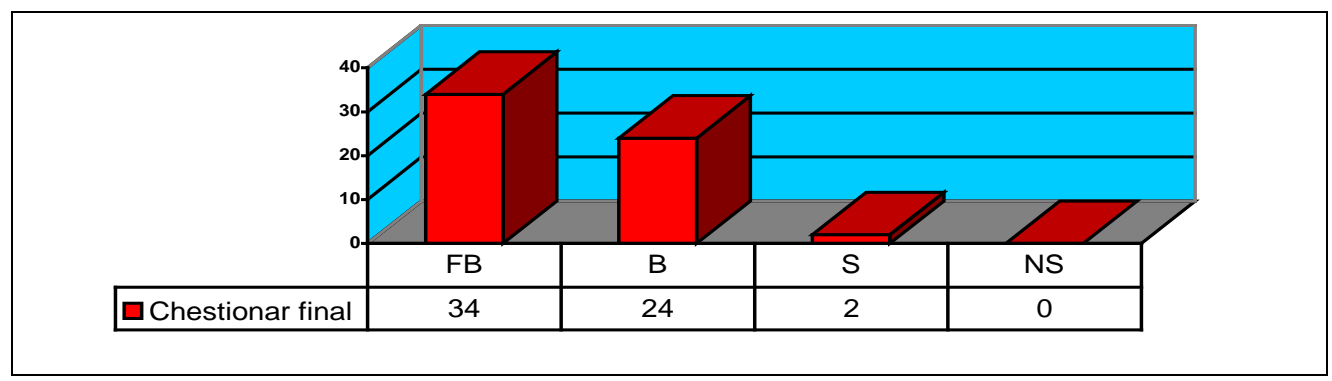

Figura 2. Dinamica evoluţiei rezultatelor pentru întrebarea 2

Conform graficului 2 privind dinamica evoluţiei rezultatelor pentru întrebarea 2, putem constata o distribuţie bimodală a rezultatelor către $\mathrm{o}$ apreciere foarte bună $56 \%$, o apreciere bună $40 \%$ iar satisfăcătoare 3,3\%.

3. Cât de importante, adecvate, oportune şi explicite vi s-au părut exemplele practice prezentate?

\begin{tabular}{|c|c|c|c|}
\hline Foarte bună & Bună & Satisfăcătoare & Nesatisfăcătoare \\
\hline 52 & 7 & 1 & \\
\hline
\end{tabular}

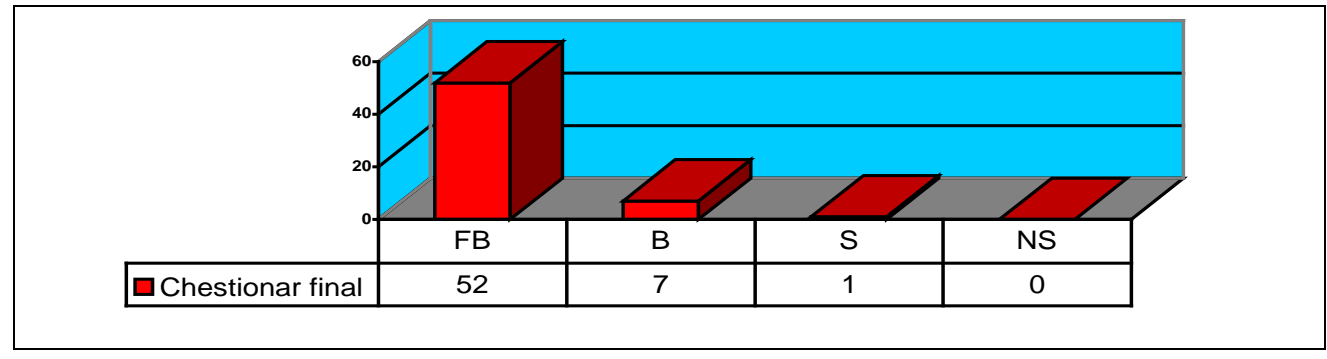

Figura 3. Dinamica evoluţiei rezultatelor pentru întrebarea 3

Conform graficului 3 privind dinamica evoluţiei rezultatelor pentru întrebarea 3, putem constata o distribuţie unidirecţionată a rezultatelor către o apreciere foarte bună $80,6 \%$, o apreciere bună $11,6 \%$ iar satisfăcătoare $1,6 \%$.

4. Cum apreciaţi relaţia student-tutore? Vă rugăm să scrieţi: FB (foarte bine), B (bine), S (satisfăcător) sau N (nesatisfăcător)?

\begin{tabular}{|c|c|c|c|c|}
\hline $\begin{array}{c}\text { Stilul de } \\
\text { lucru }\end{array}$ & $\begin{array}{c}\text { Modul de } \\
\text { prezentare al } \\
\text { exemplelor }\end{array}$ & $\begin{array}{c}\text { Abilităţile de } \\
\text { comunicare şi } \\
\text { de feedback }\end{array}$ & $\begin{array}{c}\text { Cunoaşterea } \\
\text { subiectului }\end{array}$ & $\begin{array}{c}\text { Apreciere } \\
\text { generală }\end{array}$ \\
\hline $\begin{array}{c}\text { FB }-53 / \mathrm{B}- \\
6 / N S-1\end{array}$ & $\begin{array}{c}\text { FB }-52 / \mathrm{B}- \\
7 / \mathrm{S}-1\end{array}$ & $\begin{array}{c}\mathrm{FB}-45 / \mathrm{B}- \\
13 / \mathrm{S}-2\end{array}$ & $\begin{array}{c}\mathrm{FB}-44 / \mathrm{B}- \\
14 / \mathrm{S}-2\end{array}$ & $\begin{array}{c}\mathrm{FB}-49 / \mathrm{B}- \\
9 / \mathrm{S}-2\end{array}$ \\
\hline
\end{tabular}




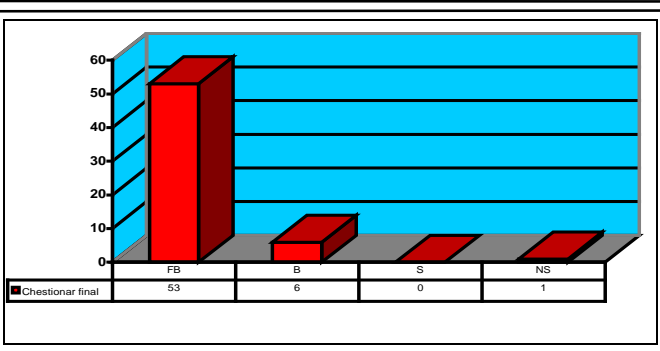

Figura 4. Dinamica evolutiei rezultatelor pentru întrebarea 4 - Stilul de lucru

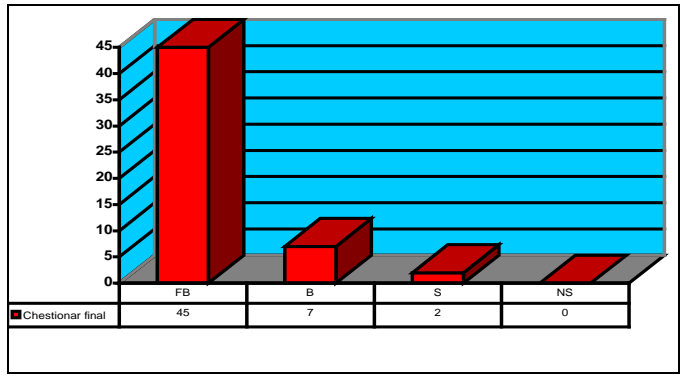

Figura 6. Dinamica evoluţiei rezultatelor pentru întrebarea 4 - Abilităţile de comunicare şi de feedback

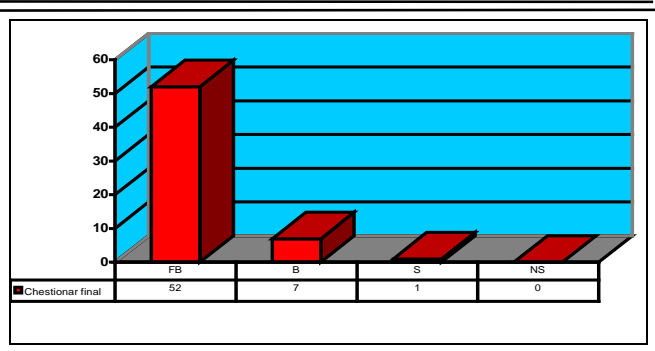

Figura 5. Dinamica evoluţiei rezultatelor pentru întrebarea 4 - Modul de prezentare al exemplelor

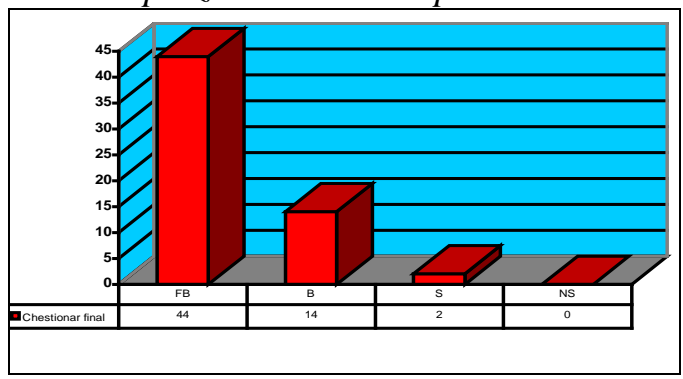

Figura 7. Dinamica evoluţiei rezultatelor pentru întrebarea 4 - Cunoaşterea subiectului

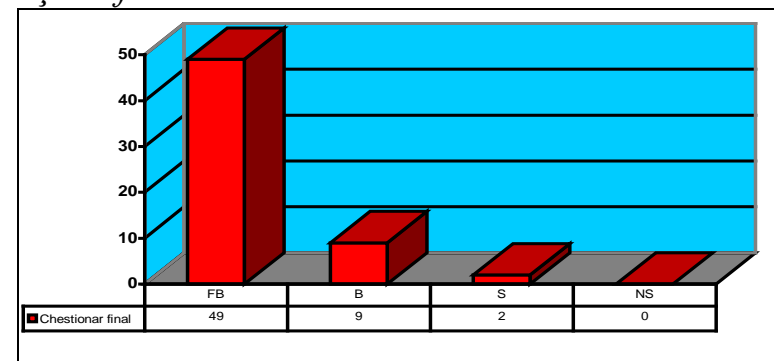

Figura 8. Dinamica evoluţiei rezultatelor pentru întrebarea 4 - Apreciere generală

Conform graficului 4 privind dinamica evoluţiei rezultatelor pentru întrebarea 4 - Stilul de lucru, putem constata o distribuţie unidirecţionată a rezultatelor către o apreciere foarte bună $80,8 \%$, o apreciere bună $10 \%$ iar nesatisfăcătoare $3,3 \%$. Conform graficului 5 privind dinamica evoluţiei rezultatelor pentru întrebarea 4 - Modul de prezentare al exemplelor, putem constata o distribuţie unidirecţionată a rezultatelor către o apreciere foarte bună $80,6 \%$, o apreciere bună $11,6 \%$ iar satisfăcătoare $1 \%$. Conform graficului 6 privind dinamica evoluţiei rezultatelor pentru întrebarea 4 - Abilităţile de comunicare şi de feedback, putem constata o distribuţie unidirecţionată a rezultatelor către o apreciere foarte bună $75 \%$, o apreciere bună $21,6 \%$ iar satisfăcătoare 3,3\%. Conform graficului 7 privind dinamica evoluţiei rezultatelor pentru întrebarea 4 - Cunoaşterea subiectului, putem constata o distribuţie unidirecţionată a rezultatelor către o apreciere foarte bună $73 \%$, o apreciere bună $23,3 \%$ iar satisfăcătoare 3,3\%. Conform graficului 8 privind 
dinamica evoluţiei rezultatelor pentru întrebarea 4 - Apreciere generală, putem constata o distribuţie unidirecţionată a rezultatelor către o apreciere foarte bună $81,6 \%$, o apreciere bună $15 \%$ iar satisfăcătoare $3,3 \%$.

5. Consideraţi că stagiul de practică a contribuit la pregătirea dvs. profesională şi la acomodarea cu mediul viitoarei activităţi practice facilitând, în acelasi timp, accesul pe piaţa muncii?

\begin{tabular}{|c|c|c|c|}
\hline Foarte mult & Mult & Semnificativ & Deloc \\
\hline 47 & 12 & 1 & \\
\hline
\end{tabular}

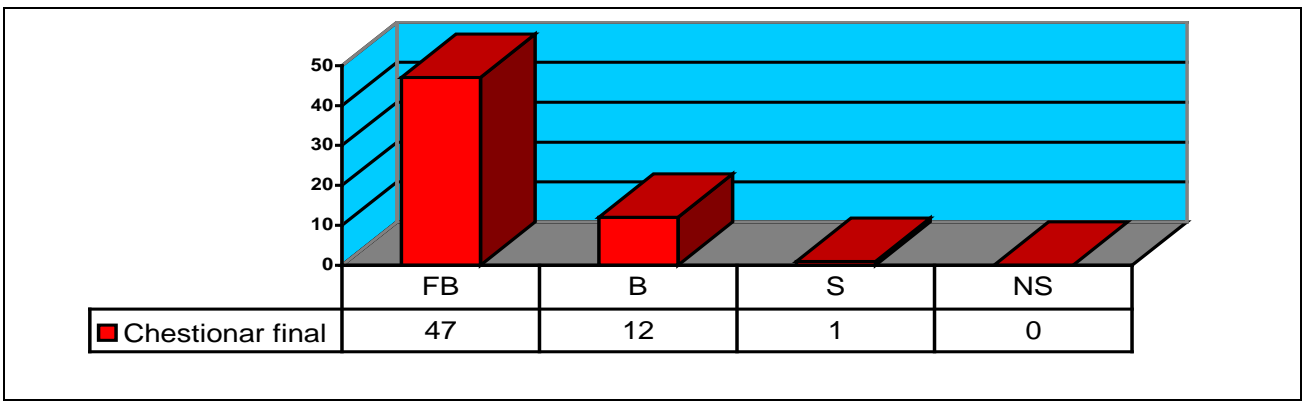

Figura 9. Dinamica evoluţiei rezultatelor pentru întrebarea 5

Conform graficului 9 privind dinamica evoluţiei rezultatelor pentru întrebarea 5, putem constata o distribuţie unidirecţionată a rezultatelor către o apreciere foarte bună $78,3 \%$, o apreciere bună $20 \%$ iar nesatisfăcătoare $1 \%$.

\section{Concluzii}

Concluziile generale ce se desprind în urma finalizării proiectului au fost următoarele:

Dintre competenţele profesionale şi cele transversale (conform Matricii Cadrului Naţional al Calificărilor din Învăţământul Superior CNCIS Grila 1L Descrierea domeniului/programului de studii prin competenţe profesionale şi competenţe transversale, http://portal.unitbv.ro/) oferite de către activităţile de practică desfăsurate în centrele menţionate, amintim:

\begin{tabular}{|c|c|}
\hline $\begin{array}{c}\text { Competenţe transversale generale şi } \\
\text { specifice }\end{array}$ & Competenţe profesionale \\
\hline $\begin{array}{l}\text { - Executarea responsabilă a sarcinilor } \\
\text { profesionale, în condiţii de autonomie } \\
\text { restrânsă şi asistenţă calificată - } \\
\text { Organizarea de programe } \\
\text { kinetoterapeutice in condiţii de asistenţă } \\
\text { calificată, cu respectarea normelor de } \\
\text { etică şi deontologie profesională; }\end{array}$ & $\begin{array}{l}\text { - Evaluarea clinică primară } \\
\text { (funcţională) şi diagnoza nevoilor } \\
\text { de intervenţie kinetoterapeutică. } \\
\text { - Realizarea programelor de } \\
\text { intervenţie kinetoterapeutică, cu } \\
\text { caracter profilactic, curativ sau de } \\
\text { recuperare. }\end{array}$ \\
\hline
\end{tabular}


- Familiarizarea cu rolurile şi activităţile specifice muncii în echipă şi distribuirea de sarcini pentru nivelurile subordonate Îndeplinirea $\hat{\imath}$ condiţii de eficienţă şi eficacitate a sarcinilor de lucru pentru organizarea şi desfăşurarea activităţilor specifice intervenţillor kinetoterapeutice;

- Conştientizarea nevoii de formare continuă; utilizarea eficientă a resurselor şi tehnicilor de învăţare, pentru dezvoltarea personală şi profesională - Autoevaluarea obiectivă a nevoii de formare profesională în scopul insertiei şi adaptabilităţii la cerinţele pieţei muncii, potrivit propriului proiect de dezvoltare personală.

- Utilizarea metodelor şi
tehnicilor de intervenţie
kinetoterapeutică.
- Utilizarea elementelor de
management şi marketing specifice
domeniului.

Concluziile generale ce se desprind în urma finalizării proiectului au fost următoarele:

- cunoştinţele, aptitudinile şi competenţele dobândite de către participanţi în urma absolvirii stagiilor de practică îi vor ajuta să se adapteze mult mai uşor la noile cerinţe ale pieţii muncii;

- ca urmare a dezvoltării şi îmbunătăţirii competenţelor profesionale acestea pot avea efecte pozitive asupra vieţii economice şi sociale în ansamblu.

Această lucrare are la bază activitatea depusă în cadrul Proiectelor de tip POSDRU/189/2.1/G/156348 cu titlul - „Creşterea angajabilităţii personale a studenţilor prin stagii de practică performante, consiliere profesională şi orientare în carieră - O şansă în plus!" şi POSDRU/189/2.1/G/156336 „Sprijinirea studenţilor în tranziţia spre viaţa activă prin stagii de practică specializate, orientare în carieră şi consiliere profesională - Sprijin pentru viitor!”. 